\title{
LIGNANS IN OAT AND BARLEY GRAINS DEPENDING ON GENOTYPE AND FARMING PRACTICE
}

\author{
Māra Bleidere ${ }^{1}$, Sanita Zute ${ }^{1}$, Natālija Gailāne ${ }^{2}$, Ināra Kantāne ${ }^{2}$, Ida Jākobsone ${ }^{2, \#,}$ \\ and Vadims Bartkevičs ${ }^{2,3}$

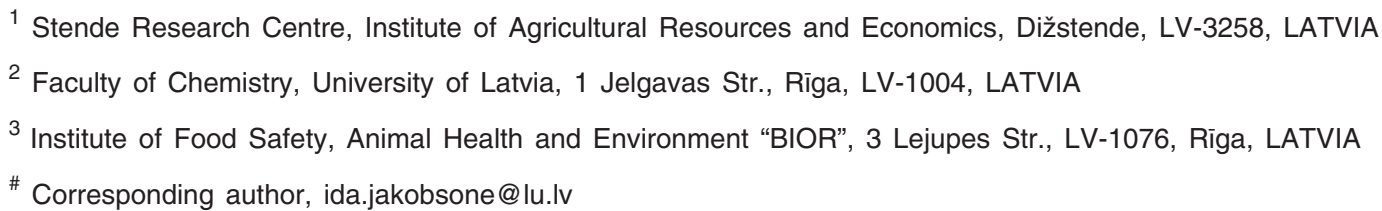

Contributed by Sanita Zute

\begin{abstract}
Cereals are an important source of vitamins, minerals, dietary fibre, and various phytochemicals, such as plant lignans. Lignans are a group of phenolic compounds that are commonly found in plants as their secondary metabolites. Lignans, found also in foodstuffs such as grains and seeds, are biologically active antioxidants, which reduce the occurrence of diabetes and cardiovascular diseases and prevent the progression of breast and prostate cancer. The aim of the study was to determine concentrations of lignans in different barley and oat genotypes grown under organic and conventional farming practices. Samples were collected in 2013 und 2014. The concentration of lignans was determined by high-performance liquid chromatography coupled with tandem mass spectrometry (HPLC-MS/MS). The highest concentration of total lignans was found in oat grains: $507.1 \pm 3.0$ (509.2 in 2013 and 505.0 in 2014) $\mu \mathrm{g} \cdot 100^{-1} \mathrm{~g}$. In barley grains, total lignin concentration was $425.2 \pm 30.3$ (403.8 in 2013 and 446.6 in 2014) $\mu \mathrm{g} \cdot 100^{-1} \mathrm{~g}$ were detected. Concentration of some lignans, like HO-Mata, Lari and Pino, was higher both in oat (450.0, 3323 and $1159.8 \mu \mathrm{g} \cdot \mathrm{kg}^{-1}$, respectively) and barley grain $\left(334.3,3297\right.$ and $334.4 \mu \mathrm{g} \cdot \mathrm{kg}^{-1}$, respectively). The lignan concentration in studied oat and barley samples did not differ significant depending on cultivation practice.
\end{abstract}

Key words: Avena sativa L., Hordeum vulgare L., Seco, HO-Mata, Lari, Pino, Mata, HPLCMS/MS.

\section{INTRODUCTION}

Phytoestrogens are biologically active compounds that naturally occur in a variety of plants, which may form part of the human diet. Structurally similar to 17ß-estradiol (endogenous estrogens), they are diphenolic compounds, divided into several subclasses, including lignans and isoflavones (Grace et al., 2003a; Kuijsten et al., 2005; Idehen et al., 2017). Phytoestrogens are receiving increasing attention due to potential protective effect against a wide range of human health problems, including breast, prostate, bowel, and other cancers, cardiovascular diseases, brain function, osteoporosis, and menopausal symptoms (Valentin-Blasini et al., 2000; Grace et al., 2003a; 2003b; Peterson et al., 2010; Soleymani et al., 2020).

Lignans are phenolic compounds found in plants, and some are converted to mammalian lignans in humans. They are found in all cereals and especially in whole grain and bran products, since they are concentrated in the outer layers of the grain (Smeds et al., 2007).

Lignans contain a diphenolic ring system based around a 2,3-disubstituted dibenzylbutane backbone. Lignans occur in foods as aglycones or as mono- and diglycosides (Grace et al., 2003b). Lignans are biologically active antioxidants that have been shown to reduce the occurrence of diabetes and cardiovascular disease, and prevent the progression of breast and prostate cancer when used in animal models. Lignans can be used as food supplements in pharmaceutical and nutritional applications due to their protective role in disease prevention (Popova et al., 2009). Lignans are found in foodstuffs such as grains and seeds. In the Western hemisphere most of the lignans consumed derive from wholegrain cereals, legumes, other vegetables, some fruits and 
berries, olive oil, wines, tea, and coffee (Kuijsten et al., 2005; Adlercreutz, 2007).

In a recent review (Zalešak et al., 2019), the authors found 300 peer-reviewed articles about studies on lignan and neolignane conducted between 2016 and mid 2018. They categorised 413 novel compounds and summarised their biological activity by chemical structure. Also, the previously described compounds were discussed.

After ingestion, plant lignans are converted by human intestinal bacteria to enterodiol (End) and enterolactone (Enl), known as mammalian lignans. End and Enl have been described as the major lignans present in serum, urine, bile, and seminal fluids of animals, including humans (Grace et al., 2003a; Kuijisten et al., 2005; Krajčová et al., 2009).

Due to different consumption patterns and variation in microflora, plasma concentrations of End and Enl vary widely between persons. For example, Kilkkinen et al. (2001) reported Enl concentrations between 0 and $100 \mathrm{nmol} \cdot \mathrm{l}^{-1}$ in men $(\mathrm{n}=1168)$ and 0 and $180 \mathrm{nmo} \cdot \mathrm{l}^{-1}$ in women $(\mathrm{n}=$ 1212). Another study (Adlercreutz et al. 1993), found higher concentrations in vegetarians - up to $1000 \mathrm{nmol} \cdot \mathrm{l}^{-1}$, $\mathrm{n}=14$.

End and Enl are also called enterolignans. They have demonstrated antioxidant and weak (anti-) estrogenic effects (Kuijsten et al., 2005).

The aim of the study was to determine concentrations of lignans in barley and oat samples, depending on genotype and cultivation practice.

\section{MATERIALS AND METHODS}

All experiments were carried out from 2013 to 2014 at the Institute of Agricultural Resources and Economics (AREI) Stende Research Centre (Latvia). Spring barley (Hordeum vulgare L.) and oat (Avena sativa L.) genotypes (varieties and breeding lines) created in AREI were cultivated under two conditions - organically and conventionally (Table 1).

Organic field. The soil type was sod-podzolic sandy loam (Eutric Abeluvisols). Organic matter content was 21.6-22.3 $\mathrm{g} \cdot \mathrm{kg}^{-1}, \mathrm{pH}_{\mathrm{KCl}}$ 5.70-6.10, and concentration of plantavailable phosphorus $\left(\mathrm{P}_{2} \mathrm{O}_{5}\right) 138-153 \mathrm{mg} \cdot \mathrm{kg}^{-1}$ and potassium $\left(\mathrm{K}_{2} \mathrm{O}\right)-142-170 \mathrm{mg} \cdot \mathrm{kg}^{-1}$. Common agronomic practices for organic management were used during the vegetation period.

Conventional field. The soil type was sod-podzolic sandy loam (Eutric Abeluvisols). Organic matter content was 20.4-21.5 g. $\mathrm{kg}^{-1}, \mathrm{pH}_{\mathrm{KCl}}$ 5.4-5.9, available phosphorus $\left(\mathrm{P}_{2} \mathrm{O}_{5}\right)$ concentration was $140.0-170.8 \mathrm{mg} \cdot \mathrm{kg}^{-1}$ and potassium $\left(\mathrm{K}_{2} \mathrm{O}\right)-185.3-205.0 \mathrm{mg} \cdot \mathrm{kg}^{-1}$. The experimental treatment consisted of three $\mathrm{N}$ rates (N80, N120, and N160) in conventional growing conditions. Complex mineral fertiliser was used as a basic fertiliser at the rate $725 \mathrm{~kg} \cdot \mathrm{ha}^{-1}(\mathrm{~N}-$ $80 \mathrm{~kg} \cdot \mathrm{ha}^{-1}, \mathrm{P}-28.6$, and $\mathrm{K}-112.4 \mathrm{~kg} \cdot \mathrm{ha}^{-1}$ ). The $\mathrm{N}$ applica-
Table 1. Evaluated barley and oat genotypes

\begin{tabular}{lll}
\hline \multicolumn{1}{c|}{ Genotype } & \multicolumn{1}{c}{ Origin } & \multicolumn{1}{c}{ Description } \\
\hline $\begin{array}{l}\text { Barley } \\
1185\end{array}$ & Simba/Wanubet & $\begin{array}{l}\text { hulless barley breeding } \\
\text { line }\end{array}$ \\
Kornelija & $\begin{array}{l}\text { SCBN852.7/Sauce/3/Mola// } \\
\text { Schuri//Arupo*2/Jet }\end{array}$ & $\begin{array}{l}\text { naked barley variety } \\
\text { (breeding line IC 360) }\end{array}$ \\
1165 & $\begin{array}{l}\text { Gainer/Freedom } \\
\text { KM246-3.78/Taifun }\end{array}$ & $\begin{array}{l}\text { naked barley breeding line } \\
\text { widely grown malting bar- } \\
\text { ley variety }\end{array}$ \\
Oats & Selma/NosNacht & naked oat variety \\
Stendes Emilija & Sreeding line S-156) \\
33793 & Nosnacht/Stmara & naked oat breeding line \\
Lizete & Dzintara//Sovetskij/Premis/ & new hulled oat variety \\
& 3/STL1986 &
\end{tabular}

tion was split with part of the $\mathrm{N}$ being applied at the time of sowing and the remaining half at the end of tillering stage (growing stage/GS 29) of the crop. Ammonium nitrate (N 34\%) was used a top-fertiliser in the following amounts: $40 \mathrm{~kg} \mathrm{~N} \cdot \mathrm{ha}^{-1}$ (N120) and $80 \mathrm{~kg} \mathrm{~N} \cdot \mathrm{ha}^{-1}$ (N160). The treatments were laid out in a randomised complete block design; the plot size was $10 \mathrm{~m}^{2}$, four replicates.

Weather conditions. Average daily temperature in 2013 and 2014 exceeded the long-term average or norm by 0.6 to $3.5{ }^{\circ} \mathrm{C}$ in May and in July. Dry conditions in both years of the study occurred in July (41.6\% of the norm in 2013 and $59 \%$ in 2014). Differences among years were observed in the average daily temperature in June - temperature above norm in 2013, and below norm in 2014; this month in both years was rich with precipitation (130\% of the long term average in 2013 and $174.9 \%$ in 2014).

Sample preparation. Sampling was done according to ISO 950 Cereals-Sampling (as grain). Approximately $200 \mathrm{mg}$ of whole-grain flour was treated with $5.0 \mathrm{ml} 70 \%$ methanol containing $0.3 \mathrm{M} \mathrm{NaOH}$ for $1 \mathrm{~h}$ at $60{ }^{\circ} \mathrm{C}$. After incubation, the samples were cooled to room temperature and centrifuged for $10 \mathrm{~min}$ at $10{ }^{\circ} \mathrm{C}$ and $4500 \mathrm{rpm}$ in order to precipitate salts. The supernatant was transferred to a fresh tube and the extraction was repeated. The supernatants were pooled, pH was adjusted to 5-6 using glacial acetic acid $(\sim 90 \mu \mathrm{l})$ and the samples were centrifuged. An aliquot of $8.5 \mathrm{ml}$ of this solution was withdrawn for enzymatic hydrolysis (Kuijisten et al., 2005; Krajčová et al., 2009). An aliquot was evaporated under $\mathrm{N}_{2}$ stream $\left(60^{\circ} \mathrm{C}\right)$.

Enzymatic hydrolysis. $170 \mu \mathrm{l}$ of enzyme solution ( $1 \mathrm{ml}$ of original enzyme was dissolved in $10 \mathrm{ml}$ of Na-acetate buffer getting concentration $13600 \mathrm{U} / \mathrm{ml}$; the necessary 2300 Units per sample correspond to $\sim 170 \mu$ of this enzyme diluted in buffer) was added. Then, an additional amount of buffer (0.05 M Na-acetate buffer, pH 5) was added per sample to achieve $3 \mathrm{ml}$. The mixture was incubated for 19 hours at $37{ }^{\circ} \mathrm{C}$ in a drying cabinet. Then, the mixture was cooled to room temperature and extracted with diethylether $(2 \times 2.0$ $\mathrm{ml})$. The supernatants were pooled and evaporated to dry- 
Table 2. Lignan compound concentration in oat in 2013 and $2014, \mu \mathrm{g} \cdot \mathrm{kg}^{-1}(\operatorname{mean} \pm \mathrm{SD}, \mathrm{n}=24)$

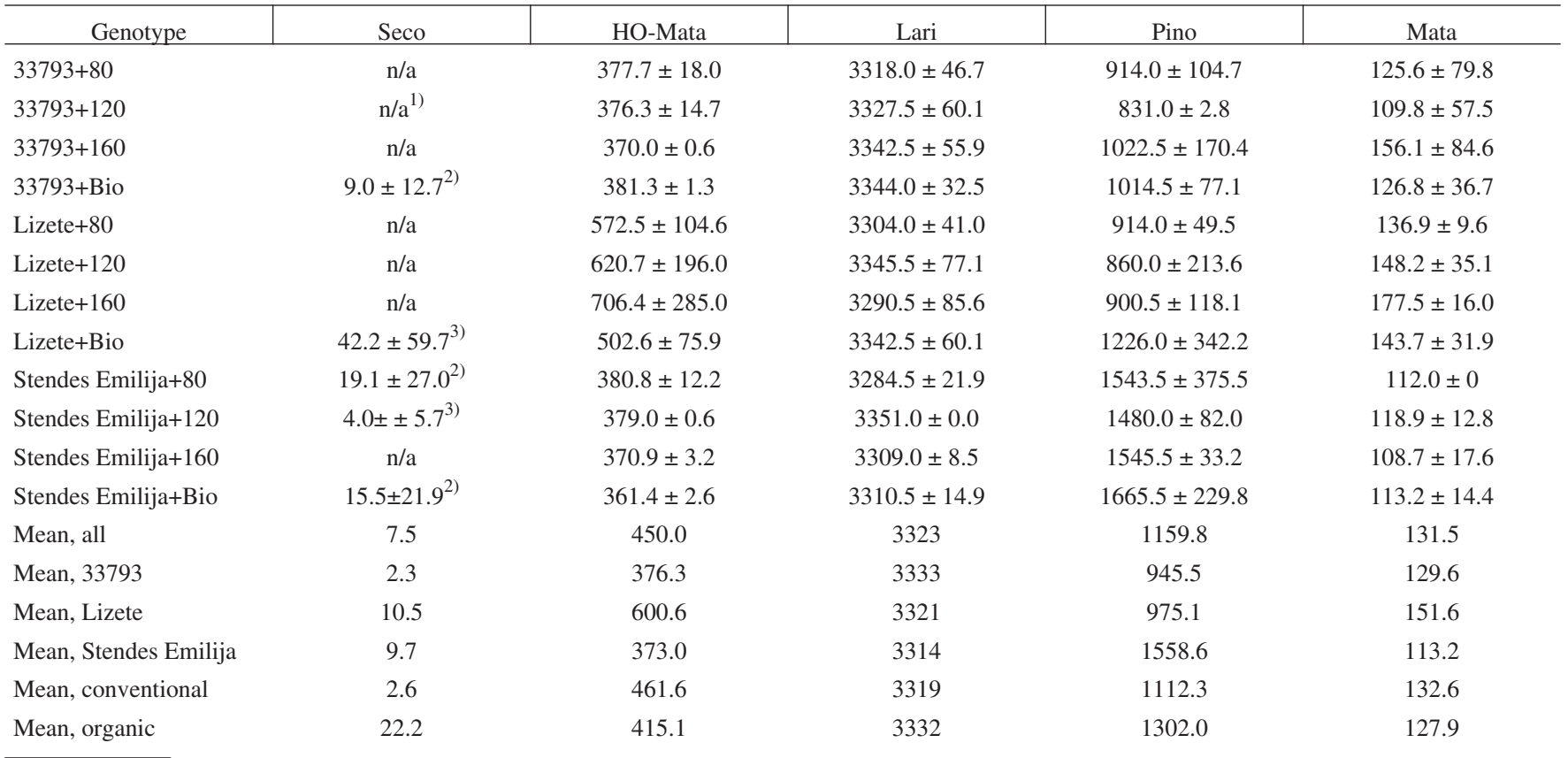

$\mathrm{SD}$, standart deviation; ${ }^{1)} \mathrm{n} / \mathrm{a}$ - not available $(5.0) ;{ }^{2)}$ only in 2013 , in $2014-\mathrm{n} / \mathrm{a} ;{ }^{3)}$ only in 2014 , in $2013-\mathrm{n} / \mathrm{a}$.

ness. Dry residue was dissolved in a solution of acetonitrile with $0.1 \%$ glacial acetic acid/ $\mathrm{H}_{2} \mathrm{O}(1: 1)$, filtered through 0.2 $\mu \mathrm{m}$ filters. This solution was then used for HPLC-MS/MS analysis. Some evaporated samples were stored for seven days in a freezer at $-21{ }^{\circ} \mathrm{C}$.

The following lignans were analysed: Seco (secoisolariciresinol), HO-Mata (7- hydroxymatairesinol), Lari (lariciresinol), Pino (pinoresinol), and Mata (matairesinol).

Data analysis. The software package IBM Corp. Released 2013, IBM SPSS Statistics for Windows, version 22.0, was used for data statistical analysis. For data analysis, the following methods were used: descriptive statistics: mean, standard deviation and inferential statistics Mann-Whitney test, Kruskal-Wallis test, t-test.

The following coding system was used to describe genotype and farming practices: ' 1185 ' $+\mathrm{BIO}$ - barley genotype grown organically; ' 1185 ' +120 - barley genotype grown conventionally with $\mathrm{N}$ supply $120 \mathrm{~kg} \cdot \mathrm{ha}^{-1}$.

\section{RESULTS}

Oat grain. The concentration of Seco was low in all samples and in many cases it was under the detection limit (Table 2). The highest HO-Mata concentration was in 'Lizete + 160 ' $\left(706.4 \mu \mathrm{g} \cdot \mathrm{kg}^{-1}\right)$. The Lari concentration was similar in all analysed oat genotypes; the highest occurred in 'Stendes Emilija' $+120\left(3351.0 \mu \mathrm{g} \cdot \mathrm{kg}^{-1}\right)$. The highest Pino concentration was in 'Stendes Emilija' +Bio $\left(1665.5 \mu \mathrm{g} \cdot \mathrm{kg}^{-1}\right)$, and the highest Mata concentration in 'Lizete+160' $\left(177.5 \mu \mathrm{g} \cdot \mathrm{kg}^{-1}\right)$ (Table 2).

The highest total lignan concentration was observed in all variants of 'Stendes Emilija' (533.3-546.4 $\mu \mathrm{g} \cdot 100 \mathrm{~g}^{-1}$ ), and the lowest concentration in '33793'+120 (464.5 $\left.\mu \mathrm{g} \cdot 100 \mathrm{~g}^{-1}\right)$ (Table 3). The lignan concentrations in oat genotypes are presented in Table 3.

In 2014, the total lignan concentration in oat genotypes was slightly lower than in 2013 (average lignan concentration in 2013 was $509.2 \mu \mathrm{g} \cdot 100 \mathrm{~g}^{-1}$, in $2014-505.0 \mu \mathrm{g} \cdot 100 \mathrm{~g}^{-1}$ ), the difference was not statistically significant $(t$-test, $p=$ $0.701)$.

The total lignan concentration in oat genotypes did not differ significantly between organic or conventional (N80, N120, N160) growing conditions (Kruskal-Wallis test, $p=$ 0.193 ), and depending on agricultural practice ( $t$-test, $p=$ $0.598)$

Barley grain. The highest Seco concentration was in variants '1165+Bio' $\left(253.9 \mu \mathrm{g} \cdot \mathrm{kg}^{-1}\right)$ and 'Kornelija'+80 (250.7 $\left.\mu \mathrm{g} \cdot \mathrm{kg}^{-1}\right)$; the variation of Seco concentration was high for all variants. The highest HO-Mata concentration was in 'Ansis+Bio' (401.6 $\mu \mathrm{g} \cdot \mathrm{kg}^{-1}$ ). The Lari concentration was similar in all analysed barley genotypes; the highest oc-

Table 3. Lignan concentration in oat in 2013 and 2014, $\mu \mathrm{g} \cdot 100 \mathrm{~g}^{-1}(\mathrm{n}=24)$

\begin{tabular}{lcccc}
\hline \multicolumn{1}{c}{ Genotype } & 2013 & 2014 & Mean \pm SD \\
\hline Stendes Emilija+80 & 564.9 & 503.1 & $534.0 \pm 43.7$ \\
Stendes Emilija+120 & 537.7 & 528.8 & $533.3 \pm 6.3$ \\
Stendes Emilija+160 & 537.8 & 529.0 & $533.4 \pm 6.3$ \\
Stendes Emilija+Bio & 564.6 & 528.7 & $546.6 \pm 25.4$ \\
Mean, all genotypes & 509.2 & 505.0 & $507.1 \pm 3.0$ \\
Mean, 33793 & 472.1 & 485.2 & $478.7 \pm 9.3$ \\
Mean, Lizete & 504.3 & 507.3 & $505.8 \pm 2.1$ \\
Mean, Stendes Emilija & 551.2 & 522.4 & $563.8 \pm 20.4$ \\
Mean, conventional & 506.5 & 499.1 & $502.8 \pm 5.2$ \\
Mean, organic & 517.3 & 522.6 & $519.9 \pm 3.7$
\end{tabular}


Table 4. Lignan compound concentration in barley in 2013 and 2014, $\mu \mathrm{g} \cdot \mathrm{kg}^{-1}$ (mean $\pm \mathrm{SD}, \mathrm{n}=32$ )

\begin{tabular}{|c|c|c|c|c|c|}
\hline Genotype & Seco & HO-Mata & Lari & Pino & Mata \\
\hline $1165+80$ & $154.1 \pm 172.1$ & $372.7 \pm 32.5$ & $3270.5 \pm 14.9$ & $451.0 \pm 63.0$ & $134.6 \pm 44.7$ \\
\hline $1165+120$ & $175.4 \pm 248.1$ & $348.4 \pm 4.5$ & $3258.5 \pm 14.9$ & $286.4 \pm 32.9$ & $117.7 \pm 17.5$ \\
\hline $1165+160$ & $98.0 \pm 115.1$ & $362.8 \pm 26.2$ & $3268.0 \pm 32.5$ & $286.3 \pm 93.2$ & $238.5 \pm 86.2$ \\
\hline 1165+Bio & $253.9 \pm 359.1$ & $342.1 \pm 0.6$ & $3251.0 \pm 38.2$ & $286.3 \pm 82.2$ & $135.8 \pm 84.6$ \\
\hline $1185+80$ & $122.4 \pm 166.0$ & $344.3 \pm 5.1$ & $3297.0 \pm 12.7$ & $356.1 \pm 175.3$ & $133.5 \pm 39.9$ \\
\hline $1185+160$ & $124.6 \pm 165.0$ & $174.0 \pm 246.1$ & $3272.5 \pm 17.7$ & $257.3 \pm 63.0$ & $130.7 \pm 23.1$ \\
\hline 1185+Bio & $140.1 \pm 198.2$ & $358.3 \pm 13.4$ & $3278.5 \pm 47.4$ & $290.2 \pm 76.7$ & $108.7 \pm 30.3$ \\
\hline Ansis +80 & $157.8 \pm 114.1$ & $363.7 \pm 4.5$ & $3312.0 \pm 12.7$ & $313.5 \pm 158.9$ & $96.3 \pm 28.8$ \\
\hline Ansis +120 & $72.0 \pm 41.7$ & $375.9 \pm 37.0$ & $3359.0 \pm 91.9$ & $385.2 \pm 216.5$ & $113.2 \pm 49.5$ \\
\hline Ansis +160 & $123.2 \pm 87.6$ & $375.8 \pm 1.3$ & $3421.0 \pm 132.9$ & $385.1 \pm 79.5$ & $124.5 \pm 49.5$ \\
\hline Ansis+Bio & $163.1 \pm 230.6$ & $401.6 \pm 17.2$ & $3301.5 \pm 88.4$ & $422.0 \pm 137.0$ & $117.7 \pm 11.2$ \\
\hline Kornelija+80 & $250.7 \pm 235.3$ & $354.7 \pm 1.9$ & $3302.5 \pm 51.6$ & $344.4 \pm 65.8$ & $101.9 \pm 46.3$ \\
\hline Kornelija+120 & $222.5 \pm 262.8$ & $352.4 \pm 11.5$ & $3296.5 \pm 64.4$ & $340.6 \pm 126.1$ & $103.0 \pm 28.7$ \\
\hline Kornelija+160 & $207.8 \pm 293.8$ & $178.5 \pm 252.4$ & $3296.5 \pm 47.4$ & $352.2 \pm 93.1$ & $110.9 \pm 59.1$ \\
\hline Kornelija+Bio & $234.8 \pm 206.8$ & $178.5 \pm 26.8$ & $3275.5 \pm 13.4$ & $352.2 \pm 115.1$ & $121.1 \pm 41.5$ \\
\hline Mean all & 162.7 & 334.3 & 3297 & 334.4 & 123.5 \\
\hline Mean 1165 & 170.4 & 356.5 & 3262 & 327.5 & 156.7 \\
\hline Mean 1185 & 122.4 & 288.8 & 3285 & 286.4 & 115.3 \\
\hline Mean Ansis & 129.0 & 379.3 & 3348 & 376.5 & 112.9 \\
\hline Mean Kornelija & 229.0 & 312.7 & 3293 & 347.4 & 109.2 \\
\hline Mean conventional & 150.9 & 323.5 & 3304 & 333.3 & 124.4 \\
\hline Mean organic & 198.0 & 366.8 & 3277 & 337.7 & 120.8 \\
\hline
\end{tabular}

$\overline{\mathrm{SD}, \text { standart deviation }}$

curred in 'Ansis+160' (3421 $\left.\mu \mathrm{g} \cdot \mathrm{kg}^{-1}\right)$. The highest Pino concentration was in ' $1165+80$ ' $\left(451.0 \mu \mathrm{g} \cdot \mathrm{kg}^{-1}\right)$, and the highest Mata concentration in ' 1165 ' $+160\left(238.5 \mu \mathrm{g} \cdot \mathrm{kg}^{-1}\right)$ (Table 4).

The highest total lignan concentration was in 'Ansis' +160 (mean $443.0 \mu \mathrm{g} \cdot 100 \mathrm{~g}^{-1}$ ), and the lowest concentration in $' 1185$ ' $+160\left(395.9 \mu \mathrm{g} \cdot 100 \mathrm{~g}^{-1}\right)$. The lignan concentrations in barley genotypes in 2013 and 2014 are presented in Table 5 .

In 2014, compared with 2013, the lignan concentration in barley genotypes was higher (see Table 5). The lignan concentration differed statistically significantly in barley genotypes between 2013 and 2014 (Mann-Whitney test, $p<$ 0.001 ). The lignan concentration in barley genotypes did not differ significantly depending on organic or conventional (N80, N120, N160) growing conditions (KruskalWallis test, $p=0.842$ ), and depending on agricultural practice (t-test, $p=0.472)$.

\section{DISCUSSION}

The aim of our study was to determine the concentration of lignan compounds in oats and barley, the most popular cereals cultivated in Latvia and with high potential as ingredients of healthy food products. We also tested the effects of genotypes of Latvian origin, farming practices (organic and
Table 5. Lignan concentration (LC) in barley in growing years 2013 and $2014,($ mean $\pm S D, n=32)$

\begin{tabular}{l|c|c|c}
\hline \multicolumn{1}{c}{ Genotype } & 2013 & 2014 & Mean \pm SD \\
\hline $1165+80$ & 415.2 & 461.1 & $438.3 \pm 32.7$ \\
$1165+120$ & 396.2 & 441.1 & $418.6 \pm 31.8$ \\
$1165+160$ & 412.6 & 438.1 & $425.4 \pm 18.1$ \\
$1165+$ Bio & 387.1 & 466.7 & $426.9 \pm 56.3$ \\
$1185+80$ & 397.8 & 452.8 & $425.3 \pm 38.9$ \\
$1185+120$ & 382.8 & 417.6 & $400.2 \pm 24.6$ \\
$1185+160$ & 362.8 & 429.0 & $395.9 \pm 46.9$ \\
$1185+$ Bio & 391.7 & 443.4 & $417.6 \pm 36.6$ \\
Ansis+80 & 430.1 & 418.5 & $442.3 \pm 8.2$ \\
Ansis+120 & 442.5 & 418.6 & $435.0 \pm 16.9$ \\
Ansis+160 & 436.6 & 449.3 & $443.0 \pm 9.0$ \\
Ansis+Bio & 428.1 & 453.0 & $440.6 \pm 17.6$ \\
Kornelija+80 & 407.1 & 463.8 & $435.4 \pm 40.1$ \\
Kornelija+120 & 401.6 & 461.4 & $431.5 \pm 42.3$ \\
Kornelija+160 & 361.8 & 467.3 & $414.6 \pm 74.6$ \\
Kornelija+Bio & 406.3 & 463.4 & $434.9 \pm 40.3$ \\
Mean all & 403.8 & 446.6 & $425.2 \pm 30.3$ \\
Mean 1165 & 402.7 & 451.8 & $427.3 \pm 34.7$ \\
Mean 1185 & 383.8 & 435.7 & $409.7 \pm 36.7$ \\
Mean Ansis & 434.3 & 434.9 & $434.6 \pm 0.4$ \\
Mean Kornelija & 394.2 & 464.0 & $429.1 \pm 49,3$ \\
Mean conventional & 403.9 & 443.2 & $423.6 \pm 27.8$ \\
Mean organic & 403.3 & 456.6 & $430.0 \pm 37.7$
\end{tabular}


conventional) and cultivation years on variation of concentration of several lignans.

According to obtained data (see Tables 2 to 5), Lari was the main component of total lignan content (TLC) of oat (65\%) and barley $(78 \%)$. Other lignans in oats are Pino $(23 \%)$, HO-Mata (9\%) and Mata (3\%). Proportion of Seco content was only $0.15 \%$. In barley the content of HO-Mata and Pino was $8 \%$ each and of Seco $-4 \%$ and Mata $-3 \%$.

Our results were compared with data from different literature sources (Table 6).

In samples from Italy (Durazzo et al., 2009; 2013) the composition of lignans differed: in oat grain the concentration of Pino was three times higher, and the concentration of Lari $\sim 3$ times lower than in Latvian oat samples. Mata was not identified in Italian oat and barley samples. Total lignan content was about $80 \%$ and $50 \%$ of the TLC in Latvian oat and barley samples, respectively.

In oat samples from the local Finland market (Peñalvo et al., 2005; Peterson et al., 2010) the TLC was similar to that of Latvian samples (in samples from Finland HO-Mata was not analysed, while syringaresinol (Syr) concentration was $352 \mu \mathrm{g} \cdot 100 \mathrm{~g}^{-1}$ and medioresinol (Med) $-40 \mu \mathrm{g} \cdot 100 \mathrm{~g}^{-1}$, which were not analysed in Latvian samples.

The concentration of Lari was lower in the samples from Finland, and the concentration of Seco, Pino, and Mata were higher.

The analysis of 55 oat samples from five genotypes in Finland (Smeds et al., 2009) in most cases showed noticeably higher lignin concentration, in comparison with Latvian samples.
High concentration of lignans was found in oat bran from Finland (Smeds et al., 2007) and in barley bran (Smeds et al., 2007; Idehen et al., 2017). This can explain the lower concentration of lignans in dehulled grain or naked grain genotypes.

Dutch and Finnish (Fineli $\left.{ }^{\circledR}\right)$ databases (Teten et al., 2013) on oat and barley mean show noticeably lower concentration of TLC, as well as Lari, Pino, and Mata concentrations, than in our samples; only concentration of Seco was higher than in Latvian samples of oat and similar to barley samples.

In general, Lari and Pino are the main components of TLC (Table 6), while proportional contents of Seco, HO-Mata, and Mata are lower.

The concentration of lignans may vary also within the same genotype as a consequence of different growing conditions, geographical location and climate.

Overall, the obtained results on lignan concentrations provide valuable additional information for food and nutrition scientists on the composition of oat and barley grain raw material grown in Latvia, which can raise future interest in this component of grain of these cereals.

\section{CONCLUSIONS}

Total lignan concentration was higher in oat grain compared with barley — difference $81.9 \mu \mathrm{g} \cdot 100 \mathrm{~g}^{-1}$. Mean concentration of some lignans, like HO-Mata, Lari, and Pino, for both cereals were high, while concentration of Seco was near the detection limit. Concentration of Mata was fairly similar in oat and barley grain.

Table 6. Lignan compound concentration and total lignan content (TLC) in oat and barley grain in different investigations, $\mu \mathrm{g} \cdot 100 \mathrm{~g}{ }^{-1} \mathrm{dry}$ weight

\begin{tabular}{|c|c|c|c|c|c|c|c|}
\hline Grains & Seco & HO-Mata & Lari & Pino & Mata & $\mathrm{TLC}^{1)}$ & Reference and notes \\
\hline Oat, & 0.75 & 45.0 & 332.3 & 115.9 & 13.2 & 507 & This research, 24 samples of 3 genotypes \\
\hline Oat & $\mathrm{n} / \mathrm{a}$ & - & 97 & 304 & $\mathrm{n} / \mathrm{a}$ & 401 & $\begin{array}{l}\text { Durazzo et al., 2013; Durazzo et al., 2009; Italian } \\
\text { farms, } 2 \text { genotypes }\end{array}$ \\
\hline Oat & 19 & - & 183 & 194 & 71 & $859^{2)}$ & $\begin{array}{l}\text { Peñalvo at al., 2005, Peterson et al., 2010, local mar- } \\
\text { ket, Finland }\end{array}$ \\
\hline Oat & $6--13$ & - & $340-599$ & 214-683 & $0-104$ & $820-2550$ & Smeds et al., 2009, 55 samples of 5 genotypes, Finland \\
\hline Oat bran & 90 & 712 & 766 & 567 & 440 & 2575 & Smeds et al., 2007, local market, Finland \\
\hline Oat and barley, mean & 13 & - & 60 & 29 & 5 & 107 & Teten et al., 2013, Dutch database \\
\hline Oat and barley, mean & 13 & - & - & - & 5 & 18 & Teten et al., 2013, Finnish $\left(\right.$ Fineli $^{\circledR}$ ) database \\
\hline Barley, & 16.3 & 33.4 & 330 & 33.4 & 12.4 & 425 & This research, 32 samples of 4 genotypes \\
\hline Barley & 28 & - & 132 & 45 & $\mathrm{n} / \mathrm{a}$ & 206 & $\begin{array}{l}\text { Durazzo et al., 2013; Durazzo et al., 2009; Italian } \\
\text { farms, } 2 \text { dehulled genotypes }\end{array}$ \\
\hline Barley & 30 & - & 85 & 72 & 3 & $359^{3)}$ & $\begin{array}{l}\text { Durazzo et al., 2013; Peńalvo at al., 2005, local market, } \\
\text { dehulled }\end{array}$ \\
\hline Barley bran & 42 & 541 & 133 & 71 & 42 & $969^{4)}$ & Smeds et al., 2007; Idehen et al., 2017 \\
\hline \multicolumn{8}{|c|}{ 1) Sum of analysed lignans } \\
\hline \multicolumn{8}{|c|}{ 2) Included $352 \mu \mathrm{g} \cdot 100 \mathrm{~g}^{-1}$ syringaresinol (Syr) and $40 \mu \mathrm{g} 100 \mathrm{~g}^{-1}$ medioresinol (Med) } \\
\hline \multicolumn{8}{|c|}{ 3) Included $169 \mu \mathrm{g} \cdot 100 \mathrm{~g}^{-1}$ syringaresinol (Syr) } \\
\hline \multicolumn{8}{|c|}{ 4) Included $140 \mu \mathrm{g} \cdot 100 \mathrm{~g}^{-1}$ syringaresinol (Syr) } \\
\hline
\end{tabular}


There were no statistically significant differences between oat genotypes, their growing conditions (conventional or organic) and year of growing (weather conditions). However, lignan concentration in grain of the naked oat variety 'Stendes Emilija" was higher than in covered barley genotypes - mean difference $71.6 \mu \mathrm{g} \cdot 100 \mathrm{~g}^{-1}$.

There was no considerable difference in total lignin concentration among investigated covered and naked barley genotypes. The total lignan concentration in barley genotypes did not differ significantly depending on organically or conventionally growing conditions. The total lignan concentration in barley genotypes was higher in 2014 in comparison with 2013, and the differences were statistically significant. This suggests that weather conditions of the growing year can influence lignin concentration of barley grains.

\section{ACKNOWLEDGMENTS}

The authors acknowledge financial support from the European Social Fund project No. 2013/0072/1DP/1.1.1.2.0/13/ APIA/VIAA/032.

\section{REFERENCES}

Adlercreutz, H., Fotsis, T., Lampe, J., Wahala, K., Makela, T., Brunow, G., Hase, T. (1993). Quantitative determination of lignans and isoflavonoids in plasma of omnivorous and vegetarian women by isotope dilution gas chromatography-mass spectrometry. Scand. J. Clin. Labor. Investig., 215, 5-18. DOI: $10.3109 / 00365519309090693$.

Adlercreutz, H. (2007). Lignans and human health. Crit. Rev. Clin.Labor. Sci., 44 (5-6), 483-525. DOI: 10.1080/10408360701612942.

Alexander, P. D., Alloway, B. J., Dourado, A. M. (2006). Genotypic variation in the accumulation of $\mathrm{Cd}, \mathrm{Cu}, \mathrm{Pb}$ and $\mathrm{Zn}$ exhibited by six commonly grown vegetables. Environ. Poll., 144, 736-745.

https://doi.org/10.1016/j.envpol.2006.03.001(accessed 15.01.2022).

Durazzo, A., Raguzzini, A., Azzini, E., Foddai, M. S., Narducci, V., Maiani, G., Carcea, M. (2009). Bioactive molecules in cereals. Techn. Molit. Int., 60, $150-162$.

Durazzo, A., Zaccaria, M., Polito, A., Maiani, G., Carcea, M. (2013). Lignan content in cereals, buckwheat and derived foods. Foods, 2 (1), 53-63. DOI: 10.3390/foods 2010053 .

Grace, B. P., Taylor, J. I., Botting, N. P., Fryatt, T., Oldfield, M. F., Al-Maharik, N., Bingham, S. A. (2003a). Quantification of isoflavones and lignans in serum using isotope dilution chromatography/tandem mass spectrometry. Rapid. Commun. MassSpectrom., 17, 1350-1357. DOI: $10.1002 / \mathrm{rcm} .1059$

Grace, B. P., Taylor, J. I., Botting, N. P., Fryatt, T., Oldfield, M. F., Bingham, S. A. (2003b). Quantification of isoflavones and lignans in urine using gas chromatography/mass spectrometry. Anal. Biochem., 315, 114-121. DOI: 10.1016/s0003-2697(02)00707-8.

Idehen, E., Tang, Y., Sang, S. (2017). Bioactive phytochemicals in barley. J. Food Drug Anal., 25, 148-161. DOI: 10.1016/j.jfda.2016.08.002.

Kilkkinen, A., Stumpf, K., Pietinen, P., Valsta, L. M., Tapanainen, H., Adlercreutz, H. (2001). Determinants of serum enterolactone concentration. Amer. J. Clin. Nutr., 73, 1094-1100.

https://doi.org/10.1093/ajcn/73.6.1094 (accessed 15.01.2022).
Krajčová, A., Schulzová, V., Hajšlová, J., Bjelková, M. (2009). Lignans in flaxseed. Czech J. Food Sci., 27, 252-255.

https://doi.org/10.17221/1062-CJFS (accessed 15.01.2022).

Kuijsten, A., Buijsman, M., Arts, I., Mulder, P., Hollman, P. A. (2005). Validated method for the quantification of enterodiol and enterolactone in plasma using isotope dilution liquid chromatography with tandem mass spectrometry. J. Chromatogr. B, 822, 178-184.

https://doi.org/10.1016/j.jchromb.2005.06.004 (accessed 15.01.2022).

Landete, J. M. (2012). Plant and mammalian lignans: A review of source, intake, metabolism, intestinal bacteria and health. Food Res. Int., 46 (1), $410-424$.

https://doi.org/10.1016/j.foodres.2011.12.023 (accessed 15.01.2022).

Mazur, W. (2000). Phytoestrogens: Occurrence in foods, and metabolism of lignans in man and pigs. Academic dissertation. Medical Faculty of the University of Helsinki, Finland.

https://helda.helsinki.fi/bitstream/handle/10138/22638/phytoest.pdf?sequence $=2$ (accessed 15.01.2022)

Peñalvo, J. L., Haajanen, K. M., Botting, M., Adlercreutz, H. (2005). Quantification of lignans in food using isotope dilution gas chromatographie / mass spectrometrie. J. Agric. Food Chem., 53, 9342--9347. https://pubmed.ncbi.nlm.nih.gov/16302745/ (accessed 15.01.2022).

Peterson, J., Dwyer, J., Adlercreutz, H., Scalbert, A., Jacques, P., McCullough, M. I. (2010). Dietary lignans: Physiology and potential for cardiovascular disease risk reduction. Nutr. Rev., 68 (10), 571-603. https://doi.org/10.1111/j.1753-4887.2010.00319.x (accessed 15.01.2022).

Popova, E. I., Hall, C., Kubátová, A. (2009). Determination of lignans in flaxseed using liquid chromatography with time-of-flight mass spectrometry. J. Chromatogr. A, 2, 217-229.

https://doi.org/10.1016/j.chroma.2008.11.063 (accessed 15.01.2022).

Smeds, I. A., Hakala, K.,Hurmerinta, T. T., Kortela, L., Saarinen, N. M., Mäkelä, S. I. (2006). Determination of plant and enterolignans in human serum by high-perfomance liquid chromatography with tandem mass spectrometric detection. J. Pharm. Biomed. Anal., 41 (3), 898-905. https://doi.org/10.1016/j.jpba.2005.12.036 (accessed 15.01.2022).

Smeds, A. I., Eklund, P. C., Sjöholm, R. E., Willför, S. M., Nishibe, S., Deyama, T., Holmbom, B. R. (2007). Quantification of a broad spectrum of lignans in cereals, oilseeds, and nuts. J. Agric. Food Chem., 55 (4), 1337-1346. https://doi.org/10.1021/jf0629134 (accessed 15.01.2022).

Smeds, A. I., Jauhiainen, L., Tuomola, E., Peltonen-Sainio, P. (2009). Characterization of variation in the lignan content and composition of winter rye, spring wheat, and spring oat. J. Agric. Food Chem., 57 (13), 5837-5842. https://doi.org/10.1021/jf9004274 (accessed 15.01.2022).

Soleymani, S., Habtemariam, S., Rahimi, R., Nabivi, S. M. (2020). The what and who of dietary lignans in human health: Special focus on prooxidant and antioxidant effects. Trends Food Sci. Techn., 106, 382-390. https://doi.org/10.1016/j.tifs.2020.10.015 (accessed 15.01.2022).

Tetens, I., Turrini, A., Tapanainen, H., Christensen, T., Lampe, J. W., Fagt, S., Håkansson, N., Lundquist, A., Hallund, J., Valsta, L. M. (2013). Dietary intake and main sources of plant lignans in five European countries. Food Nutr. Res., 57. DOI: 10.3402/fnr.v57i0.19805.

Valentin-Blasini, L., Blount, B. C., Rogers, H. S., Needham, L. L. (2000). HPLC-MS/MS method for the measurement of seven phytoestrogens in human serum and urine. J. Expos. Anal. Environ. Epidem., 10, 799-807. https://doi.org/10.1038/sj.jea.7500122 (accessed 15.01.2022).

Zalešak, F., Bon, D., J-Y., D., Pospišil, J. (2019). Lignans and neolignans: Plant secondary metabolites as a reservoir of biologically active substances. J. Pharm. Res., 146, 104284. https://doi.org/10.1016/j.phrs.2019.104284 (accessed 15.01.2022). 


\section{LIGNĀNI AUZU UN MIEŽU GRAUDOS ATKARĪBĀ NO GENOTIPA UN LAUKSAIMNIECĪBAS PRAKSES}

Graudaugi ir nozīmīgs vitamīnu, minerālvielu, diētiskās šķiedras un dažādu fitoḳimisko vielu, piemēram, augu lignānu avots. Lignāni ir fenola savienojumu grupa, tie parasti atrodas augos kā to sekundārie metabolīti. Lignāni ir atrasti arī graudos un to pārstrādes produktos. Lignāni ir bioloǵiski aktīvi antioksidanti, kuri mazina diabēta, sirds un asinsvadu slimību rašanos, novērš krūts un prostatas vēža progresēšanu. Pētījuma mērḳis bija noteikt lignānu daudzumu Latvijā selekcionētu miežu un auzu škirṇu un līniju graudos atkarībā no lauksaimniecības prakses. Auzas un mieži tika audzēti bioloǵiski un konvencionāli. Paraugi analīzēm vākti 2013. un 2014. gadā. Lignānu saturu noteica ar augstas izšḳirtspējas šḳidruma hromatogrāfiju ar tandēma masspektrometriju (HPLC-MS/MS). Lielākie kopējo lignānu daudzumi tika konstatēti auzu graudos: 507,1 \pm 3.0 (509,2 2013. gadā un 505,0 2014. gadā) $\mu \mathrm{g} \cdot 100 \mathrm{~g} \mathrm{~g}^{-1}$. Miežu graudos 425,2 \pm 30,3 (403,8 2013. gadā un 446,6 2014. gadā) $\mu \mathrm{g} \cdot 100 \mathrm{~g}^{-1}$. Dažu lignānu, piemēram, HO-Mata, Lari un Pino, saturs bija lielāks gan auzu (attiecīgi 450,0, 3323 un $1159,8 \mu \mathrm{g} \cdot \mathrm{kg}^{-1}$ ), gan miežu graudos (attiecīgi 334,3, 3297 un $334,4 \mu \mathrm{g} \cdot \mathrm{kg}^{-1}$ ). Lignānu koncentrācija auzu un miežu genotipu graudos atkarībā no pielietotās lauksaimniecības prakses būtiski neatšḳīrās. 